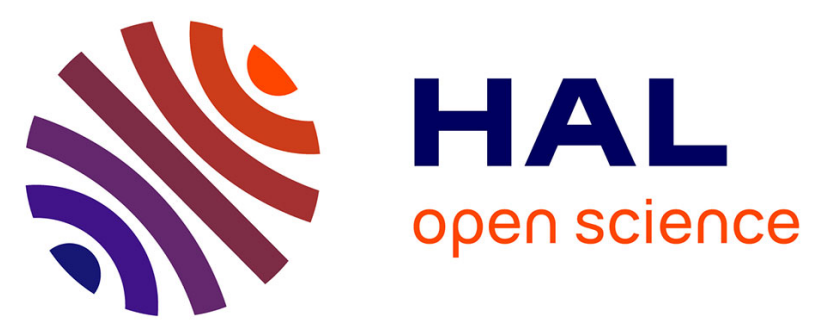

\title{
Grain scale processes recorded by oxygen isotopes in olivine-hosted melt inclusions from two MORB samples
}

Mélina Manzini, Anne-Sophie Bouvier, Lukas Baumgartner, Estelle F. Rose-Koga, Pierre Schiano, Nobumichi Shimizu

\section{- To cite this version:}

Mélina Manzini, Anne-Sophie Bouvier, Lukas Baumgartner, Estelle F. Rose-Koga, Pierre Schiano, et al.. Grain scale processes recorded by oxygen isotopes in olivine-hosted melt inclusions from two MORB samples. Chemical Geology, 2019, 511, pp.11-20. 10.1016/j.chemgeo.2019.02.025 . hal02055503

\author{
HAL Id: hal-02055503 \\ https://hal.uca.fr/hal-02055503
}

Submitted on 13 Nov 2020

HAL is a multi-disciplinary open access archive for the deposit and dissemination of scientific research documents, whether they are published or not. The documents may come from teaching and research institutions in France or abroad, or from public or private research centers.
L'archive ouverte pluridisciplinaire HAL, est destinée au dépôt et à la diffusion de documents scientifiques de niveau recherche, publiés ou non, émanant des établissements d'enseignement et de recherche français ou étrangers, des laboratoires publics ou privés. 


\section{Grain scale processes recorded by oxygen isotopes in olivine-}

\section{2 hosted melt inclusions from two MORB samples}

3

4 Mélina Manzini ${ }^{1}$, Anne-Sophie Bouvier ${ }^{*}$, Lukas P. Baumgartner ${ }^{1}$, Estelle F. Rose-Koga ${ }^{2}$, $5 \quad$ Pierre Schiano ${ }^{2}$, Nobumichi Shimizu ${ }^{3}$

6

7

8 inclusions hosted in olivine from two samples from the Mid-Atlantic ridge. Melt inclusions 22 from different crystals within the same sample show more than $2.5 \%$ o $\delta^{18} \mathrm{O}$ variation within

${ }^{1}$ Institute of Earth Sciences, University of Lausanne, 1015 Lausanne, Switzerland

(melina.manzini@gmail.com; anne-sophie.bouvier@unil.ch; lukas.baumgartner@unil.ch)

${ }^{2}$ Laboratoire Magmas et Volcans, University of Blaise Pascal-CNRS-IRD, Clermont-Ferrand, France

(estelle.koga@uca.fr; p.schiano@opgc.fr)

${ }^{3}$ Woods Hole Oceanic Institution, Woods Hole, MA 02543, USA

(nshimizu@,whoi.edu)

*Corresponding author: A.-S. Bouvier (anne-sophie.bouvier@unil.ch)

\section{Abstract}

Although olivine-hosted melt inclusions from mid ocean ridge basalts (MORB) are commonly used as a proxy for mantle composition, these melt inclusions generally show larger elemental and isotopic compositional variation than their host lavas and the origin of these heterogeneities remains disputed. Here we present oxygen isotope data from melt 
each sample, which is nearly eight times the analytical error of $0.3 \%$ ( 2 standard deviations) and five times the $\delta^{18} \mathrm{O}$ range in unaltered MORB. Measured $\delta^{18} \mathrm{O}$ in melt inclusions do not correlate with common magmatic tracers, and $\delta^{18} \mathrm{O}$ measured in the host olivines suggest a maximum of $1 \% \delta^{18} \mathrm{O}$ source heterogeneity. Less than half of the melt inclusions from each sample are in equilibrium with their host crystals; the remaining melt inclusions have either lower or higher olivine-melt oxygen isotope partition coefficients compared to the theoretical equilibrium values. Here we discuss several potential processes that could contribute to these observations, but none satisfactorily explain the olivine-melt inclusion oxygen disequilibrium that we observe in these samples. Nevertheless, it seems clear that the variability of $\delta^{18} \mathrm{O}$ in melt inclusion from two MORB samples do not record only common magmatic process(es), but rather a localized grain scale process. Any $\delta^{18} \mathrm{O}$ variation in melt inclusions should thus be interpreted with caution.

\section{Keywords}

Olivine-hosted melt inclusions; MORB; Mid-Atlantic Ridge; oxygen isotopes; grain scale processes; heterogeneity; SIMS

\section{Introduction}

Olivine-hosted melt inclusions are often used to study the origin and evolution of mantlederived magmas (for a review, see Kent, 2008; Schiano, 2003 and references therein). Melt inclusions are physically isolated from their host magma, which undergoes different processes during magmatic evolution after the entrapment of melt inclusions (for example, magma mixing, assimilation, degassing). An important observation is that larger elemental and 
isotopic compositional variations are generally observed in melt inclusions when compared to whole-rock or glass compositions. A widespread interpretation is that variations measured in melt inclusions reflect magmatic diversity that is not recorded in whole rock compositions due to obscuration during later processes (e.g., Kent, 2008). In some cases, variations could also be related to small-scale reactions in the melt in which the olivine is growing (Danyushevsky et al., 2004).

In mid-oceanic ridge basalts (MORB), most melt inclusions have trace-element compositions in the range of MORB lavas, but there are also some clear exceptions to this general observation (see Schiano, 2003 for a review). These 'anomalous' trace-element compositions have usually been interpreted to reflect near-fractional melting of a depleted mantle and/or spinel lherzolite, or of hydrothermally altered peridotite (e.g., Gurenko and Chaussidon, 1995; Nielsen et al., 2000; Sobolev and Shimizu, 1993). The anomalous trace-element compositions are not found in MORB rocks, as MORBs represent aggregates of different melt fractions (e.g., Jin et al., 1994; McKenzie, 1984; Sobolev and Shimizu, 1993). Melt reaction within the crust, i.e. within a crystal mush, may also explain the larger compositional variations observed in some MORB melt inclusions compared to lavas (e.g., Danyushevsky et al., 2004; Kamenetsky and Gurenko, 2007).

Major and trace element variability in melt inclusions from MORB samples are also sometimes observed within a single phenocryst (Shimizu, 1998), which indicates that melt inclusions are not necessarily in equilibrium with their hosts. Such small-scale diversity could be generated by trace element diffusion within the melt during melt inclusion formation by host dissolution-reprecipitation, or by boundary layer entrapment during fast, diffusioncontrolled growth or melt transport (e.g., Baker, 2008; Cottrell et al., 2002; Faure and

69 Schiano, 2005; Manzini et al., 2017; Van Orman et al., 2002). Other processes, such as 
responsible, in some cases, for elemental variation in melt inclusions (e.g., Danyushevsky et al., 2000a; Gaetani et al., 2012).

To date, no stable isotope data from melt inclusions within olivine from typical MORB samples have been published. Although $\delta^{11} \mathrm{~B}$ and $\delta^{18} \mathrm{O}$ were reported in some olivine-hosted melt inclusions from Iceland, the petrogenetic history of these samples is fundamentally different from typical MORB settings (Gurenko and Chaussidon, 1997, 2002; Hartley et al., 2013). In this study, we focus on $\delta^{18} \mathrm{O}$ values from melt inclusions within MORB samples, as the systematics of this stable isotope system are well constrained. Based on a compilation of $\delta^{18} \mathrm{O}$ data in Neogene volcanic rocks, Harmond and Hoefs (1995) concluded that bulk MORB rocks have $\delta^{18} \mathrm{O}$ compositions of $5.7 \%$ o $\pm 0.2 \%$. Because the variation reported is similar to the typical analytical uncertainty reported in the literature for individual $\delta^{18} \mathrm{O}$ measurements of silicate rocks at that time, the authors concluded that MORB have a uniform $\delta^{18} \mathrm{O}$ signature. More recently, fresh MORB glasses from the Mid-Atlantic Ridge, Indian Ocean and east Pacific Ridge were analyzed by laser fluorination and show a narrow range of oxygen isotope ratios from $5.37 \pm 0.01$ to $5.81 \pm 0.04 \%$ o $(1 \sigma)$, with an average of $+5.50 \%$ (Eiler et al., 2000). In addition, $\delta^{18} \mathrm{O}$ is thought to not fractionate during melting (e.g., Eiler, 2001). As such, if melt inclusions are representative of the MORB source, they should show similar values within a relatively restricted range; however, as melt inclusions generally show larger chemical variations than those recorded by the bulk rock, $\delta^{18} \mathrm{O}$ in melt inclusions from MORB samples might also display larger isotopic variabilities than MORB glasses. Constraining the variability of oxygen isotopes in melt inclusions from MORB samples is important, as $\delta^{18} \mathrm{O}$ variations within these melt inclusions serve to assess the importance of fluid interaction, magma mixing and/or assimilation of oceanic crust (Gurenko and Chaussidon, 2002; Hartley et al., 2013). In this study we report $\delta^{18} \mathrm{O}$ data from melt inclusions within two different MORB samples from the northern Mid-Atlantic Ridge. We observe a 
never before reported large range of $\delta^{18} \mathrm{O}$ compositions within these melt inclusions, up to $2.5 \%$, and discuss the reported data in term of magmatic processes, olivine dissolutionprecipitation and diffusion.

\section{Sample description and geological context}

The studied olivine-hosted melt inclusions are from two dredged basalts from the North Atlantic ridge. Sample ARP73-10-03 is a picrite from the FAMOUS zone $\left(36^{\circ} 8372^{\prime} N\right.$, $33^{\circ} 2482^{\prime} \mathrm{W}$ ) that contains a little more than $20 \%$ olivine phenocrysts (Fo87.2-91.3), rare clinopyroxene, and plagioclase xenocrysts. The crystals are surrounded by a hyalocrystalline groundmass composed of glass, plagioclase $\left(\mathrm{An}_{75-80}\right)$ and olivine microlites (Fo86) (Laubier et al., 2007). Laubier et al. (2007) suggest that the variable major and trace element compositions of ARP73-10-03 melt inclusions reflect polybaric partial melting of a homogeneous mantle, followed by mixing in various proportions at either different degrees of melting or in different parts of the melting system.

CH77-DR6-203 is a dredged basalt from the $14^{\circ}$ MAR triple junction $\left(14.12^{\circ} \mathrm{N}, 45^{\circ} \mathrm{W}\right)$. This fresh sample is highly enriched in volatiles, with $\mathrm{CO}_{2}$ in vesicles and water in the glass, (popping rock; Javoy and Pineau, 1991) and shows a compositional anomaly with enriched $(\mathrm{Nb} / \mathrm{Zr})_{\mathrm{N}},(\mathrm{Ta} / \mathrm{Hf})_{\mathrm{N}}$ and $(\mathrm{La} / \mathrm{Sm})_{\mathrm{N}}$ compared to adjacent segments which may result from mantle heterogeneity (Bougault et al., 1988). The mantle heterogeneity hypothesis is also supported by $\mathrm{Sr}$ and $\mathrm{Nd}$ isotopes in $\mathrm{MORB}$ rocks from different segments of the triple junction (Dosso and Bougault, 1986). The melt inclusions studied here are hosted in 1-5 mm, polyhedral olivines containing one or several melt inclusions. They are glassy, sub-spherical, and have a radius of $40-350 \mu \mathrm{m}$. They contain no daughter minerals. Rare shrinkage bubbles are present, but represent only a small fraction of the total volume. 
121 Methods

\section{Sample preparation}

124 Polished olivines containing exposed melt inclusions were pressed into 1-inch indium mounts, 125 along with the glass standards (BHVO-2G, BCR-2G and BIR-1G) and San Carlos olivine. 126 Care was taken to mount them within $8 \mathrm{~mm}$ of the center of the mount. A separate mount was 127 made for each sample. SEM images were acquired at the University of Lausanne using a

128 Tescan Mira LMU field-emission scanning electron microscope operated at $20 \mathrm{kV}$ and $0.2-0.4$ 129 nA probe current to ensure that the melt inclusions were totally glassy. Melt inclusions with 130 cracks or crystals were discarded. Topography of each mount was measured using a Brucker 131 GTA-K white light interferometer.

\section{Electron microprobe}

134 Major element compositions and X-ray distribution maps of melt inclusions and olivines were 135 acquired using a JEOL 8200 Superprobe electron microprobe analyzer. Analytical conditions 136 for the quantitative measurement of olivine were $15 \mathrm{kV}$ at $20 \mathrm{nA}$ and a $5 \mu \mathrm{m}$ beam diameter. 137 Counting times were $30 \mathrm{~s}$ for $\mathrm{Si}, \mathrm{Mg}, \mathrm{Mn}$ and $\mathrm{Fe}$ and $40 \mathrm{~s}$ for $\mathrm{Al}, \mathrm{Ca}, \mathrm{Ni}$ and $\mathrm{Cr}$. Analytical 138 conditions for analyses of melt inclusions were $15 \mathrm{kV}, 10 \mathrm{nA}$ and a $10 \mu \mathrm{m}$ beam diameter. 139 Counting times were $30 \mathrm{~s}$ for all elements except for $\mathrm{K}(20 \mathrm{~s})$ and $\mathrm{Na}(16 \mathrm{~s})$. A glass standard 140 (KL2-G) was used for $\mathrm{SiO}_{2}$ and $\mathrm{Al}_{2} \mathrm{O}_{3}$. All other elements were calibrated on minerals. A 141 grain of ML3B-G was used as an internal standard to check the calibration. 
144 Oxygen isotope ratios, volatiles $\left(\mathrm{H}_{2} \mathrm{O}, \mathrm{CO}_{2}, \mathrm{Cl}, \mathrm{F}\right)$ and trace-element (Ti, V, Sr, Y, Nb, Ba, $145 \mathrm{La}, \mathrm{Ce}, \mathrm{Nd}, \mathrm{Sm}, \mathrm{Eu}, \mathrm{Yb}$ ) concentrations were determined using the CAMECA ims1280-HR at 146 the SwissSIMS laboratory.

147

148

150

151

\section{Oxygen isotopes}

Analytical conditions were similar to those described by Seitz et al. (2017): Throughout ${ }^{18} \mathrm{O} /{ }^{16} \mathrm{O}$ measurements of melt inclusions and olivines, the sample was sputtered with a $\mathrm{Cs}^{+}$ primary beam of $2 \mathrm{nA}$, which was raster over $15 \mu \mathrm{m}$. An electron gun was utilized in order to compensate for sample charging. Samples were pre-sputtered for $30 \mathrm{~s}$, followed by $80 \mathrm{~s}$ of analysis (20 cycles of 4 s). Automatic centering of secondary ions on field and contrast apertures were performed before each analysis. Measurements of ${ }^{16} \mathrm{O}$ and ${ }^{18} \mathrm{O}$ were performed simultaneously via two Faraday cups, using $10^{10}$ and $10^{11}$ resistors, respectively. The intensity of ${ }^{16} \mathrm{O}$ was typically $\sim 2.2 \times 10^{9}$ counts per second for glasses and $\sim 1.7 \times 10^{9}$ counts per second for olivine. Internal error (2 standard error), reflecting the counting statistics of one analysis, was usually better than $0.3 \%$ for melt inclusions and olivines.

For melt inclusions, instrumental mass fractionation (IMF) was corrected using a set of 9 international glass standards with compositions ranging from basaltic to rhyolitic (NKT-1G, GOR132-2G, BIR-2G, BHVO-2G, ML3B-2G, BCR-2G, StHs6/80G, UoE-Lipari, ATHO-G; Hartley et al., 2012; Jochum et al., 2006). The matrix effect was corrected using a linear regression of IMF with $\mathrm{SiO}_{2}$ (Figure DR1-A). Two to three standards (BHVO, BIR and BCR), with compositions closely bracketing the melt inclusion compositions, were added on each mount to monitor and correct for potential instrumental drift. For olivines, IMF was corrected using an in-house San Carlos olivine standard (Fo 90.1), as well as three in-house olivine reference materials (Fo 99.6, Fo 91.9 and Fo 37.5; Fig DR1-B). 
At the outset of each session, we performed at least eight measurements of a running standard

168 (i.e., measured repeatedly during the session; BHVO for melt inclusions sessions and San

169 Carlos for olivine sessions), in order to determine standard reproducibility (noted hereafter in

1702 standard deviation, 2SD). The 2 SDs were better than $0.3 \%$ for melt inclusions sessions,

171 and $0.4 \%$ for olivines sessions. To monitor the instrument stability, running standards were

172 measured every 8 to 12 unknowns and gave a reproducibility of $0.3 \%$ 2SD, similar to the

173 eight measurements at the outset of each session. Accuracy was checked using one of the two

174 to three standards inserted in each mounts and was similar to reproducibility $(0.3 \%$ o $2 \mathrm{SD}$ and

$175 \quad 0.4 \%$ 2SD for melt inclusions and olivines, respectively).

\section{Trace elements}

178 Phosphorous concentrations within melt inclusions were measured using the same analytical

179 conditions described by Manzini et al. (2017): Trace-element compositions of melt inclusions 180 and olivine were analyzed using a 5-6 $\mathrm{nA} \mathrm{\textrm {O } ^ { - }}$ primary ion beam, resulting in an analysis spot

181 of about $20 \mu \mathrm{m}$. A mass resolution of 5000 was used. Samples were pre-sputtered for $90 \mathrm{~s}$, 182 using a $25 \mu \mathrm{m}$ raster. Trace elements were quantified by measuring the signal from the 183 following isotopes: ${ }^{48} \mathrm{Ti},{ }^{51} \mathrm{~V},{ }^{88} \mathrm{Sr},{ }^{89} \mathrm{Y},{ }^{93} \mathrm{Nb},{ }^{138} \mathrm{Ba},{ }^{139} \mathrm{La},{ }^{140} \mathrm{Ce},{ }^{142} \mathrm{Nd},{ }^{152} \mathrm{Sm},{ }^{153} \mathrm{Eu},{ }^{172} \mathrm{Yb}$.

184 These measurements were performed in mono-collection mode by peak switching throughout 185 one analytical run on an electron multiplier (EM) collector. ${ }^{40} \mathrm{Ca}$ was measured on a FC 186 collector in the same analytical run as the other trace elements and was used as reference 187 element. Using ${ }^{40} \mathrm{Ca}$ instead of ${ }^{30} \mathrm{Si}$ (or ${ }^{28} \mathrm{Si}$ ) during melt inclusion analyses allowed us to 188 check for possible contamination by olivine throughout the analyses. A waiting time was used 189 to obtain a steady state sputtering condition, and each analysis consisted of six cycles. 190 Waiting and counting time, typical standard reproducibility and typical internal error are 
191 given in Table DR1. BHVO-2G was used as standard for melt inclusions, using the USGS certified values for the trace elements.

$\mathrm{A} \mathrm{Cs}^{+}$primary ion beam with a current of $1.5 \mathrm{nA}$ was used to measure volatile elements $\left(\mathrm{H}_{2} \mathrm{O}, \mathrm{CO}_{2}, \mathrm{Cl}, \mathrm{F}, \mathrm{S}\right)$; throughout these analyses an electron gun was used to compensate the charges and to avoid charging of the sample surface. The secondary beam was accelerated at $10 \mathrm{kV}$, and the sample was pre-sputtered applying a $15 \mu \mathrm{m}$ raster for $210 \mathrm{~s}$. Elements were measured in mono-collection mode, with a $10 \mu \mathrm{m}$ raster during 12 cycles. Total analysis time, including pre-sputtering, was approximately 14 minutes. The field aperture was set to 3000 $\mu \mathrm{m}$, entrance slit to $60 \mu \mathrm{m}$ and exit slit to $240 \mu \mathrm{m}$. This configuration allowed a mass resolution of 5000, sufficient to fully discriminate the interferences. BHVO-2G, BCR-2G, BIR-1G, ALL, NS and ALV (Helo et al., 2011) were used as standards. BHVO-2G was then used as a running standard to check instrument stability. Background was determined by analysis of a synthetic anhydrous olivine. Additional information is given in Table DR1.

\section{Results}

208 A total of 34 melt inclusions within 30 olivines were measured from sample CH77-DR6-203, 209 as were 17 melt inclusions within 13 olivines from sample ARP73-10-03. The results of these analyses are summarized in Table DR2. Oxygen isotope ratios in olivines are reported in

211 Table DR3.

212 Analyzed olivines are characterized by a high forsterite content $(\mathrm{Fo}=\mathrm{Mg} / \mathrm{Fe}+\mathrm{Mg}$ ) ranging

213 from 88.8 to 91.4 for ARP73-10-03 and from 84.0 to 90.9 for CH77-DR6-203. Major-element 214 compositions of melt inclusions were corrected for the effect of post-entrapment 
215 crystallization (PEC) of olivine at the wall of melt inclusion, using the Petrolog software

216 package (Danyushevsky and Plechov, 2011). Parameters used for Petrolog calculations are 217 summarized in the footnote of Table DR2. Our calculated PEC indicates that between 5.9 and

$21818.1 \%$ of olivine crystallized after melt inclusion trapping. Major elements are less variable 219 after PEC correction (e.g., $\mathrm{SiO}_{2}$ variation of 2.8 wt. \% before and 1.6 wt. \% after correction; 220 Table DR2), and all major-element compositions mentioned hereafter are corrected for PEC.

221 Melt inclusions from ARP73-10-03 have a narrow range of major-element compositions, with $222 \mathrm{SiO}_{2}$ ranging from 50.0-50.4 wt. \%, $\mathrm{MgO}$ from $11.2-12.8$ wt. $\%$ and $\mathrm{K}_{2} \mathrm{O}$ from $0.10-0.15$ wt. $223 \%$. CH77-DR6-203 shows a slightly larger compositional range in major elements, with $\mathrm{SiO}_{2}$ 224 content from 49.2-50.8 wt. $\%, \mathrm{MgO}$ from 7.8-10.0 wt. \%, and $\mathrm{K}_{2} \mathrm{O}$ from $0.20-0.55$ wt $\%$ 225 (Figure 1A). Major-, volatile- $(\mathrm{Cl}, \mathrm{F}, \mathrm{S})$ and trace-element concentrations measured in 226 ARP73-10-03 fall within the same range as those reported by Laubier et al. (2012) for melt 227 inclusions within the same sample and are consistent with glass N-MORB compositions 228 (Jambon et al., 1995; Naumov et al., 2014; Wallace and Carmichael, 1992). Water and $\mathrm{CO}_{2}$ 229 concentrations are also in the typical range of MORB glass values (Danyushevsky et al., 230 2000b; Magenheim et al., 1995; Wallace and Carmichael, 1992). The melt inclusions from 231 CH77-DR6-203 are enriched in volatiles (to a lower extent for $\mathrm{CO}_{2}$ ) when compared with 232 MORB glass values, and have trace-element compositions similar to typical E-MORB glasses 233 (e.g., Figure 1B modified from Gale et al., 2013). 


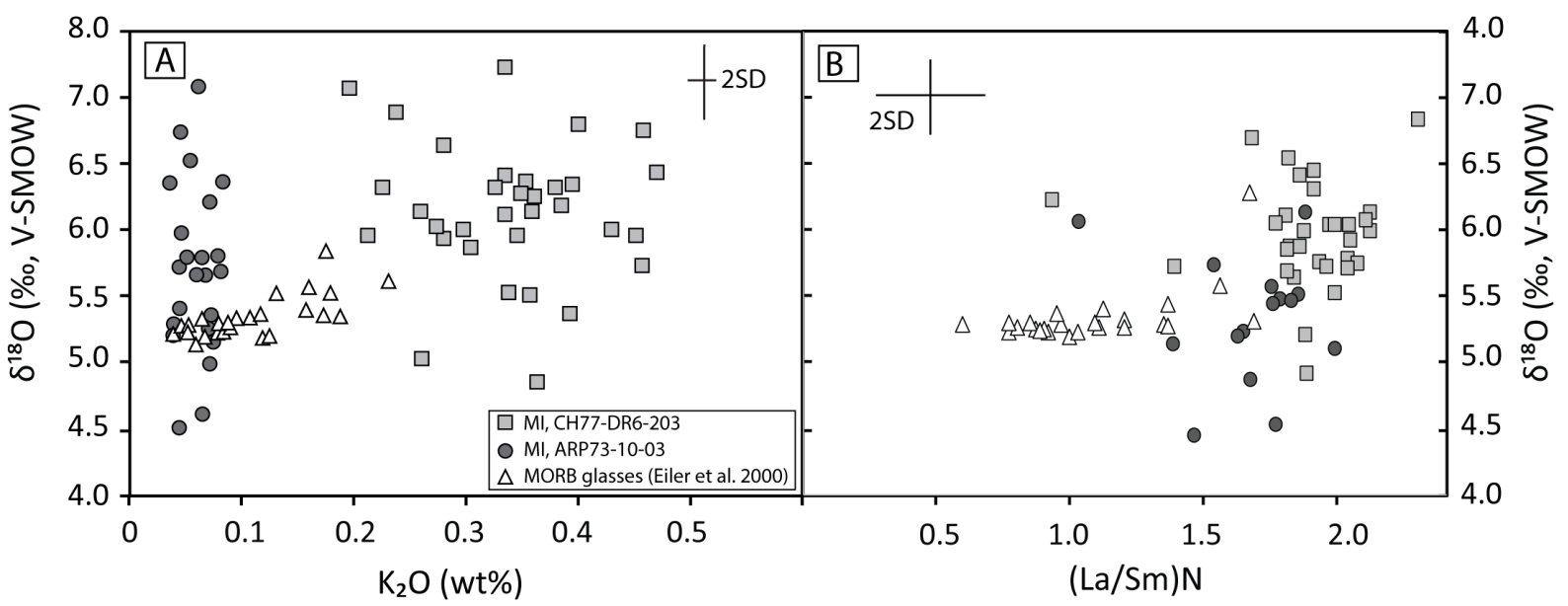

235 Figure 1: Oxygen isotope values for MI plotted against the $\mathrm{K}_{2} \mathrm{O}$ concentration (A) and the $\mathrm{La} / \mathrm{Sm}$ chondrite-normalized ratio (McDonough and Sun, 1995) (B). Line separating D-, N- and E-MORB are from Gale et al., 2013a. Fresh MORB glasses studied represented by white triangles in the figure, are plotted for comparison (Eiler et al., 2000).

240 Oxygen isotopes from melt inclusions show $>2.3 \%$ variation within each sample $\left(\delta^{18} \mathrm{O}=\right.$ $241+5.0 \pm 0.17$ to $+7.2 \pm 0.16 \%$, with an average of $+6.2 \%$ or $\mathrm{CH77-DR6-203;}$ and $\delta^{18} \mathrm{O}=+4.5$ $242 \pm 0.3$ to $+7.1 \pm 0.6 \%$, average $+5.7 \%$ o for ARP73-10-03). These variations are about eight 243 times larger than the analytical uncertainty $(0.3 \%$, $2 \mathrm{SD})$ and about five times larger than the 244 variations observed for bulk $\delta^{18} \mathrm{O}$ of unaltered MORB glasses $(<0.5 \%$; Figure 2$)$. Before IMF 245 correction, data show similar $\delta^{18} \mathrm{O}$ variations (2.2\%o). This is explained by the relatively 246 narrow range of $\mathrm{SiO}_{2}$ of the melt inclusions within a sample, which indicates that the applied 247 IMFs are relatively similar $( \pm 0.13 \%$ o $)$ for all melt inclusions from the same sample. ARP73$248 \quad 10-03$ is the closest to MORB glass composition in term of major, trace elements and oxygen 249 isotopes. Nevertheless, 8 melt inclusions out of 21 have 'anomalous' $\delta^{18} \mathrm{O}$ composition (i.e., 250 statistically - 2 SD - outside the range of MORB glass bulk values). Within a single olivine, $251 \delta^{18} \mathrm{O}$ from different melt inclusions are statistically different in the ARP73-10-03 sample (3 252 pairs, variation up to 2.2\%o), whereas in the CH77-DR6-203 sample, melt inclusions hosted in 
253 a single olivine have values within analytical uncertainty $\delta^{18} \mathrm{O}$ ( 3 pairs, variation less than $2540.4 \%$; Figure 3). In both samples, olivines show smaller variability than their hosted melt 255 inclusions: the ARP73-10-03 olivine have $\delta^{18} \mathrm{O}$ values of +4.9 to $+5.7 \%$ and olivines from 256 CH77-DR6-203 have $\delta^{18} \mathrm{O}$ ranging from +5.0 to $+6.5 \%$ (Table DR3, Figure 2).

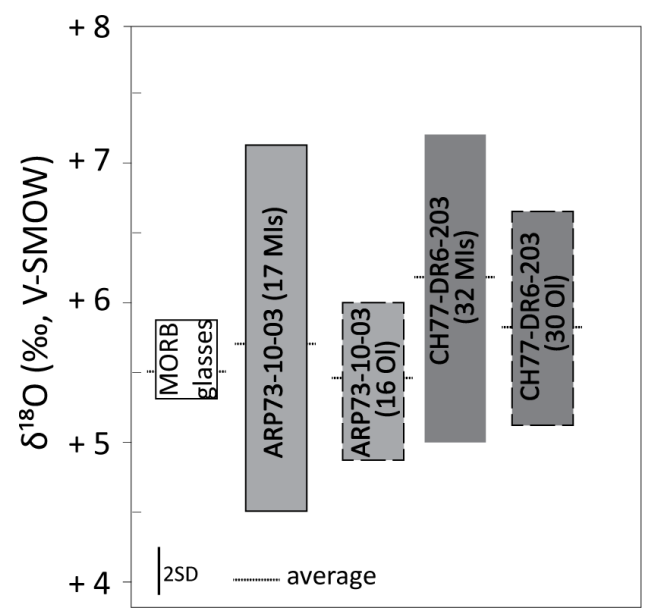

258 Figure 2: Comparison of oxygen isotope variations in MORB glasses from Mid-Atlantic Ridge, 259 Indian ocean and east-Pacific Ridge $(\mathrm{n}=28)$ (Eiler et al., 2000) and melt inclusions (MIs) from the 260 two studied MORB samples (ARP73-10-03 and CH77-DR6-203). For a comparison, range of $\delta^{18} \mathrm{O}$ 261 composition measured in the olivines hosting the melt inclusions are also plotted (dashed line 262 contoured fields). Melt inclusions show larger variability compare to MORB glasses and to their host 263 olivines. 


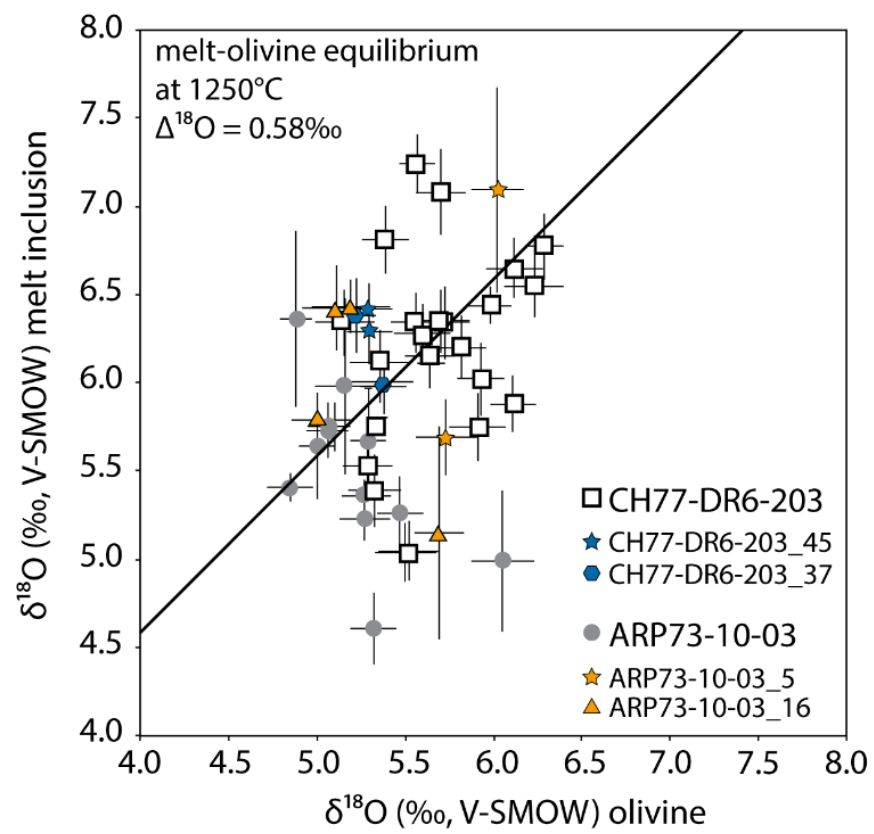

265 Figure 3: Oxygen isotope ratio of melt inclusions, compared to the $\delta^{18} \mathrm{O}$ of their host olivine crystals.

266 Melt-olivine equilibrium fractionation $\left(\Delta^{18} \mathrm{O}\right.$; black line) is from Matthews et al. (1998). Only 42 and $26746 \%$ of melt inclusions from ARP_73-10-03 and CH77-203-DR6 are in equilibrium with their host, 268 within analytical error.

\section{Discussion}

271 To date, no oxygen isotope data have been reported for olivine-hosted melt inclusions from

272 MORB samples. Only two studies (Gurenko and Chaussidon, 2002; Hartley et al., 2013)

273 reported $\delta^{18} \mathrm{O}$ in olivine-hosted melt inclusions, and these data are from 7 samples taken from

274 Iceland. These studies found $\delta^{18} \mathrm{O}$ variation reaching a maximum of $1.2 \%(+4.0$ to $+5.2 \%$,

275 sample 14161G, $\mathrm{n}=3$ melt inclusions; Gurenko and Chaussidon, 2002) and $0.95 \%$ ( +3.05 to

$276+4.0 \%$, sample N18, $\mathrm{n}=9$ melt inclusions; Hartley et al., 2013), respectively. These

277 variations were interpreted to reflect either mixing of the ascending magma with melt lenses

278 that had previously interacted with the $10 w-\delta^{18} \mathrm{O}$ Icelandic crust (Hartley et al., 2013), or

279 heterogeneity in the Icelandic mantle or mixing of two end-members (Gurenko and 
Chaussidon, 2002). Melt inclusions from the two MORB samples measured in our study both

281 show more than $2.3 \%$ variation in $\delta^{18} \mathrm{O}$, a larger variation than that reported for olivine-

282 hosted melt inclusions from Iceland. Hereafter, the $\delta^{18} \mathrm{O}$ variability is discussed in term of

283 analytical versus magmatic processes.

Analytical artefacts

286

Oxygen isotope analyses via SIMS are very sensitive to the sample geometry, i.e. the placement of the analyzed grains in the mount and the topography of the analyzed material (e.g., Kita et al., 2009). All grains and reference material have been placed within $8 \mathrm{~mm}$ of the center of the mount, in order to avoid X-Y effects due to deformation of the electrostatic field 290 close to the edge of the sample holder (Peres et al., 2013) (see methods section for more details). Reproducibility of the measurements of a homogeneous reference material for oxygen isotope is typically $<0.3 \%$ ( $2 \mathrm{SD}$ ) when the surface relief is $1 \mu \mathrm{m}$, whereas it increases up to $3 \%$ o (2SD) when topography is on the order of 10-40 $\mu \mathrm{m}$ (Kita et al., 2009).

294 Our mounts show $<4 \mu \mathrm{m}$ topography both between the indium and grains, and between 295 olivine and melt inclusions. Two different cases are presented in Figure 4: First, Figure 4-A 296 shows olivine CH77-DR6-203_37 hosting 2 melt inclusions with similar $\delta^{18} \mathrm{O}$ (within the $2970.3 \%$ 2SD calculated for a session, $+6.37 \pm 0.21 \%$ and $+5.97 \pm 0.16 \%$ ) and a topography of $2981 \mu \mathrm{m}$. Olivine ARP73-10-03_16, shown in Figure 4-B, has $\delta^{18} \mathrm{O}$ in melt inclusions which vary 299 from $+5.15 \pm 0.21 \%$ to $+6.42 \pm 0.26 \%$. This olivine has a topographical variation of up to 4 $300 \mu \mathrm{m}$, with a difference in topography of $1.5 \mu \mathrm{m}$ between melt inclusions $\mathrm{A}, \mathrm{C}$ and $\mathrm{D}$ 301 (maximum 1.3\%o difference in $\delta^{18} \mathrm{O}$ ), and $2.5 \mu \mathrm{m}$ between melt inclusions $\mathrm{A}$ and $\mathrm{B}$ (similar $\left.302 \delta^{18} \mathrm{O}\right)$. Melt inclusions are less than $1 \mu \mathrm{m}$ lower compared to the olivine, which should not 303 affect the analyses: 17 analyses made following 2 profiles along perpendicular axes from wall 
304 to wall in melt inclusion A, and 7 in melt inclusion B yield a reproducibility better than $0.3 \%$ 305 (2SD) (Table DR2). Also, multiple measurements $(n=75)$ located at the edge or in the center 306 of the olivine grain ARP73-10-03_16, which shows the largest topographical variation, yield 307 data clustering within $0.45 \%$ o (2SD; Table DR3), comparable to the reproducibility obtained 308 during the same session for San Carlos reference material that has negligible topography $309(0.40 \%, 2 S D)$. Moreover, $\delta^{18} \mathrm{O}$ from melt inclusions within ARP73-10-03_16 A and B were 310 measured twice, in two different sessions and similar values were obtained. As the mount was 311 placed in the sample holder with a different orientation, this confirms that measured $\delta^{18} \mathrm{O}$ 312 variation cannot be due to sample topography or orientation. Based on these observation, we 313 find it highly unlikely that topography of the grains is responsible for the large variation of $314 \delta^{18} \mathrm{O}$ in the melt inclusions analyzed in this study. As the calibration of the SIMS analyses 315 reported here were made using several reference materials covering the range of melt 316 inclusions major elements (Fig. DR2). Hence we conclude that the observed $\delta^{18} \mathrm{O}$ variations 317 are real in melt inclusions and do not represent analytical artefacts. 


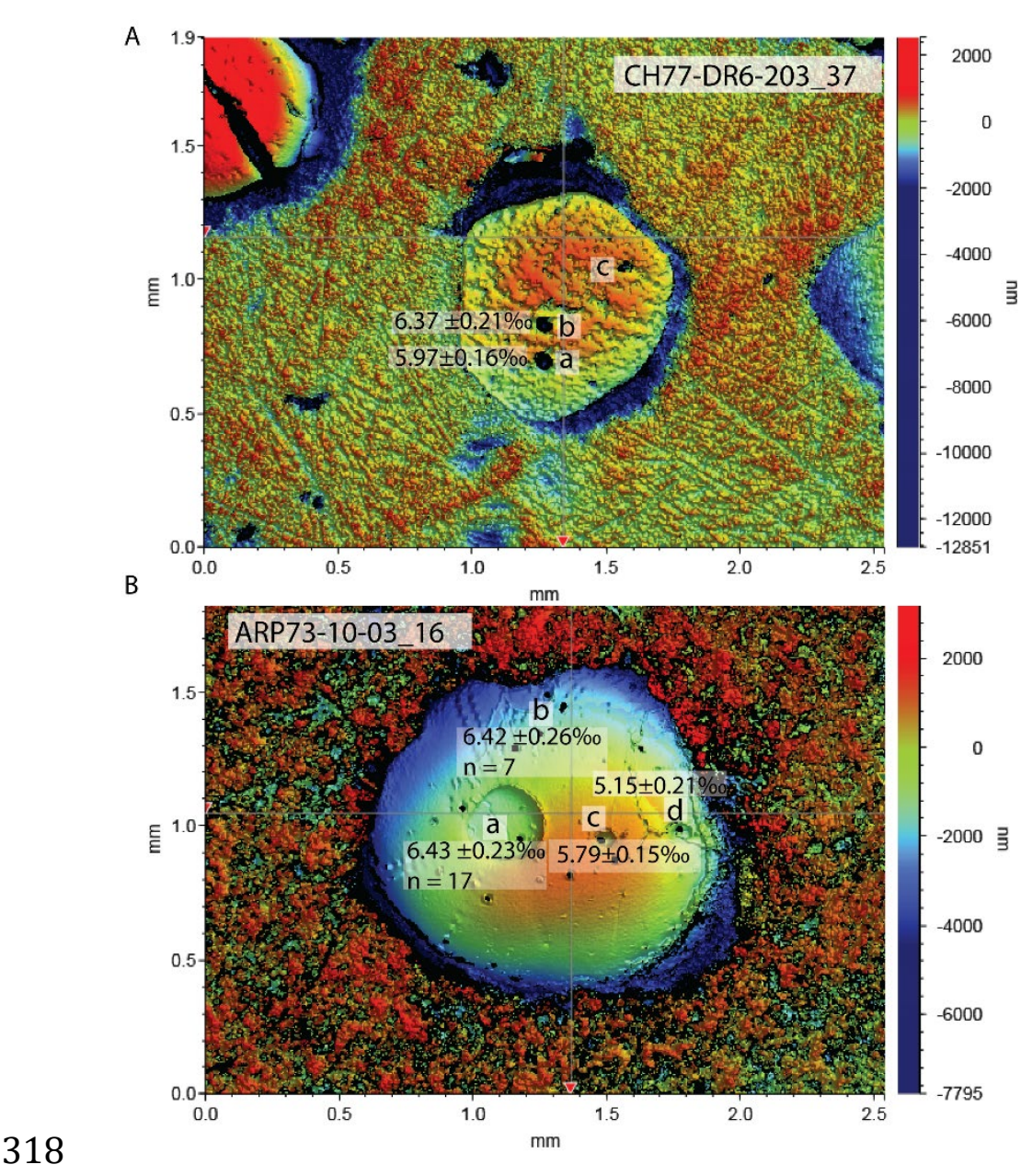

319 Figure 4: Example of profilometer images of the studied samples. A - ARP73-10-03_16 olivine; B -

320 CH77-DR6-203_37 olivine. The number of points is specified when more than one analyses was 321 obtained in the same inclusion, and the error (2SD) represents the reproducibility on the repeated 322 measurements.

325 Partial melting causes large variations in the major- and trace- element concentrations of 326 MORBs (e.g., Frey et al., 1993; Schilling et al., 1983; Zindler et al., 1979), but is not expected 327 to largely fractionate oxygen isotopes. Indeed, Bindeman et al. (2012) estimate that extraction 328 of $15 \%$ of the melt, assuming equilibrium is maintained throughout the melting, will change $329 \delta^{18} \mathrm{O}$ by only $0.05 \%$. Even high degrees of partial melting (up to $42 \%$ ) of a mantle source will 
create less than $0.2 \% \delta^{18} \mathrm{O}$ variations (e.g. Eiler, 2001). Variation in the degree of partial

331 melting will thus not be resolvable by SIMS, given the typical precision of $\sim 0.3 \%$ 2SD.

332 Hence, the lack of correlation between $\delta^{18} \mathrm{O}$ and the abundance of incompatible elements such 333 as $[\mathrm{La} / \mathrm{Sm}]_{\mathrm{N}}$ for example (Figure 1), which are sensitive to degree of melting, indicates that 334 variable extents of partial melting cannot explain the large $\delta^{18} \mathrm{O}$ scatter measured in this study. 335 Interestingly, ARP73-10-03 has a composition similar to that of typical MORB glass (N$336 \mathrm{MORB}$ ) in terms of $[\mathrm{La} / \mathrm{Sm}]_{\mathrm{N}}, \mathrm{K}_{2} \mathrm{O}$ and volatile contents, and average $\delta^{18} \mathrm{O}$ composition (e.g., 337 Eiler et al., 2000; Gale et al., 2013), whereas CH77-DR6-203 has higher $(\mathrm{La} / \mathrm{Sm})_{\mathrm{N}}$, volatiles, $338 \mathrm{~K}_{2} \mathrm{O}$ contents, and $\delta^{18} \mathrm{O}$ than that of N-MORB glass (Figure 1$)$. Differences in $(\mathrm{La} / \mathrm{Sm})_{\mathrm{N}}$, 339 volatiles and $\mathrm{K}_{2} \mathrm{O}$ contents between the two samples could reflect different degrees of 340 melting, but the different average $\delta^{18} \mathrm{O}$ rather suggests melting of an enriched mantle source 341 for CH77-DR6-203. Despite the melting of different mantle sources for the two samples, 342 resulting in different $\delta^{18} \mathrm{O}$ for their respective melt inclusions, a similar variation of $\delta^{18} \mathrm{O}$ $343(\sim 2.5 \%)$ is observed in melt inclusions for both samples.

344 The lack of correlation between $\delta^{18} \mathrm{O}$ of the melt inclusions and the forsterite content of their 345 host olivines do not support large fractionation of oxygen isotopes during magmatic evolution 346 of the studied samples (Figure 5). This observation is consistent with an experimental study 347 examining crystallization of a MORB melt dominated by olivine and plagioclase fractionation 348 (Tormey et al., 1987), which shows that the oxygen isotopic composition of the melt should 349 not vary by more than $0.1 \%$ for a $\mathrm{MgO}$ content between 3 to $8 \mathrm{wt} \%$ (Eiler, 2001). Recently, 350 Bucholz et al. (2017) modelled change in $\delta^{18} \mathrm{O}$ in tholeiite during fractional crystallization and 351 also found minor change in $\delta^{18} \mathrm{O}$ (up to $0.35 \%$ for composition comparable to ARP73-10-03 352 and CH77-203-DR3 melt inclusions). 


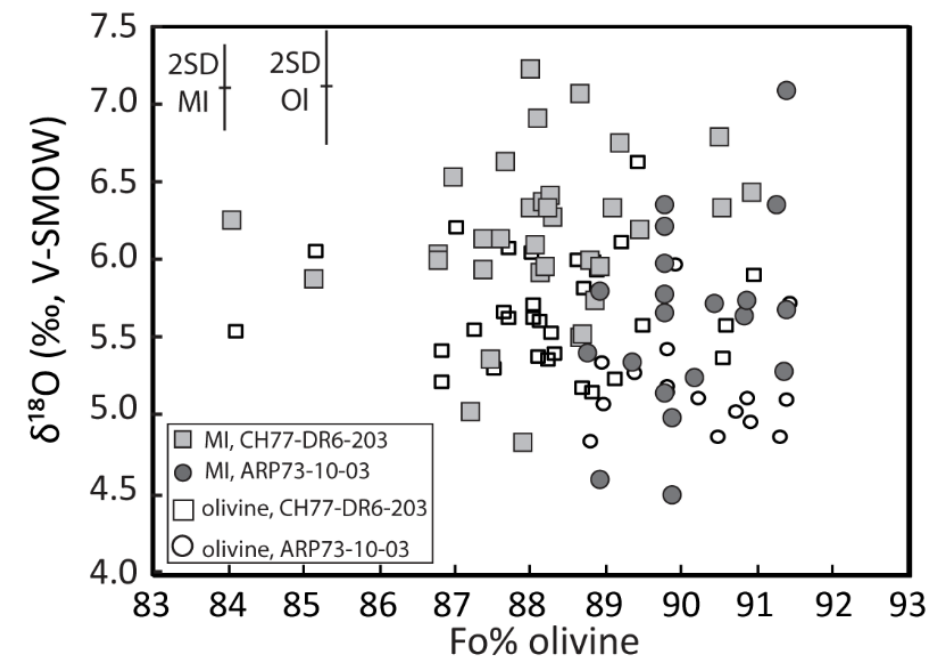

354 Figure 5: Plot of oxygen isotopes of olivine and of melt inclusions plotted against the Fo content of 355 the host olivines. Full symbols are for melt inclusions, empty symbols represent olivines.

357 Considering the low volatile concentrations in MORB lavas, the effect of magma degassing 358 on oxygen isotopes should be negligible. In fact, the total devolatilization of MORB magmas 359 will change the $\delta^{18} \mathrm{O}$ by less than $0.1 \%$ (Eiler, 2001). Similarly, oxygen fugacity changes in 360 the magmatic system should not create any oxygen isotope ratio variations as the fractionation 361 of oxygen isotopes in the melt is not controlled by $f \mathrm{O}_{2}$ (Lester et al., 2013).

362 Assimilation of altered oceanic (AOC) crust with variable $\delta^{18} \mathrm{O}(1-6 \%$ for lower AOC and 7$36315 \%$ for upper AOC; e.g. Alt, 2003; Alt and Bach, 2006) may also affect the $\delta^{18} \mathrm{O}$ variability 364 observed in melts (e.g., Genske et al., 2013). The assimilation process can be modeled by 365 simple mixing, because MORB melts and AOC have very similar oxygen concentrations. If 366 we consider a typical mantle composition of $\delta^{18} \mathrm{O}=5.5 \%$ (Eiler, 2001; Mattey et al., 1994) 367 and mix it with an altered upper oceanic crust with $\delta^{18} \mathrm{O}=15 \%$ (e.g., Alt, 2003), a minimum 368 of $17 \%$ assimilation of upper $\mathrm{AOC}$ is required to explain the highest $\delta^{18} \mathrm{O}$ measured in melt 369 inclusions (7.1\%) from ARP73-10-03. This amount of upper AOC assimilation (>17\%) 370 would, for example, result in Ba content of $>62 \mathrm{ppm}$, assuming an average Ba content of the 
371 upper AOC of 300 ppm (e.g., Kelley et al., 2003) and 13.9 ppm for uncontaminated MORB 372 (Hofmann, 1988). As melt inclusions from ARP73-10-03 (N-MORB sample), have Ba 373 contents typical of N-MORB (around $20 \mathrm{ppm}$; maximum $34 \mathrm{ppm} \mathrm{Ba}$ ), we find that 374 assimilation of upper crustal material is not likely to be responsible for the high $\delta^{18} \mathrm{O}$ values 375 measured in these melt inclusions. Similarly, a minimum of $22 \%$ assimilation of the upper $376 \mathrm{AOC}$ is required to obtain the lowest $\delta^{18} \mathrm{O}(4.5 \%)$ of the melt inclusions, assuming an 377 extreme lower AOC composition of $\delta^{18} \mathrm{O}=1 \%$ (as in hydrothermal amphibolite veins; e.g., 378 Alt and Bach, 2006). Assimilation of serpentinites that have $\delta^{18} \mathrm{O}$ values of 2.0 to $6.7 \%$, with 379 most of the values $<5 \%$ (Barnes et al., 2014; Boschi et al., 2008) would require a larger 380 amount of assimilation compared to AOC, and could not account for the $\delta^{18} \mathrm{O}$ up to $7.1 \%$ or 381 down to $4.5 \%$.

382 The absence of correlation between elements that are similarly incompatible in the dissolution 383 reactions of pyroxene, plagioclase and spinel (e.g., S and Ce; Danyushevsky et al., 2004) 384 suggests that local grain-scale dissolution-reaction mixing processes (Danyushevsky et al., 385 2004) is an unlikely process to explain the $\delta^{18} \mathrm{O}$ variations in melt inclusions. In fact, open 386 system local dissolution of minerals formed in equilibrium with a basaltic melt will not 387 change the $\delta^{18} \mathrm{O}$ composition of the ascending basaltic melt.

388 The $\delta^{18} \mathrm{O}$ variability of 1.1 and $1.4 \%$ in the olivine crystals $\left(\delta^{18} \mathrm{O}_{(\mathrm{Ol})}\right)$ from ARP73-10-03 and 389 CH77-DR6-203 (Table DR3), respectively, is an indicator that these olivine crystals record crystallization in a heterogeneous environment, or record a heterogeneous crystallization 391 history. Considering the typical reproducibility of olivine measurements of $0.4 \%$, these 392 variations are not likely to reflect analytical artefacts and should therefore represent real 393 heterogeneities. In fact, individual crystals are homogeneous within measurement uncertainty 394 of ca. $0.4 \%$, while different crystals from the same sample are more variable. In terms of major elements, each crystal is homogeneous (with the exception of $\mathrm{P}$ heterogeneities in some 
olivines; Manzini et al., 2017), but all olivines have different Fo contents (Table DR3).

Within each sample, no clear trend is observed between Fo content and average $\delta^{18} \mathrm{O}_{(\mathrm{Ol})}$ (Fig. 5). At a given Fo content, $\delta^{18} \mathrm{O}_{(\mathrm{Ol})}$ varies up to $0.9 \%$. This observation suggests that these olivine crystals from both samples grew in slightly heterogeneous environments $(\sim 0.9-1 \%$ o variation).

\section{Olivine-melt inclusion isotopic disequilibrium}

403 Equilibrium fractionation between olivine and melt $\left(\Delta^{18} \mathrm{O}_{\mathrm{ol}-\mathrm{melt}}\right)$ at $1250^{\circ} \mathrm{C}$ is $-0.6 \%$, based on 404 Matthews et al. (1998), which is equivalent to twice the uncertainty of the measured 405 compositions. As mentioned above, $\Delta^{18} \mathrm{O}$ variability in the studied melt inclusions is larger 406 than the heterogeneity of their host olivines. Only 42 and $46 \%$ of melt inclusions from 407 ARP_73-10-03 and CH77-203-DR6 are in equilibrium with their host (Figure 3). The 408 remaining melt inclusions have either lower or higher $\Delta^{18} \mathrm{O}_{\text {ol-melt }}$ compared to the theoretical 409 equilibrium value at $1250^{\circ} \mathrm{C}$. While the proportion of melt inclusions in equilibrium with their 410 host olivine is similar for both samples, the proportion of melt inclusions with higher versus 411 lower $\Delta^{18} \mathrm{O}_{\text {ol-melt }}$ is different for each sample. In detail, within an olivine containing several 412 exposed melt inclusions, $\Delta^{18} \mathrm{O}_{\text {ol-melt }}$ can vary significantly. No correlation is observed between 413 olivine-melt isotopic disequilibrium and Fo content of the host olivine, which indicates that 414 disequilibrium conditions could have prevailed at any time during the samples' magmatic 415 history. An important observation is that melt inclusions in equilibrium with their host 416 olivines do not show significant $\delta^{18} \mathrm{O}$ variation $(5.7 \pm 0.3 \%$ for ARP73-10-03 and $6.3 \pm 0.5 \%$ o 417 for CH77-203-DR6). Assuming equilibrium between olivine and melt, variations in 418 temperature throughout crystal growth could affect $\Delta^{18} \mathrm{O}_{\mathrm{ol}-\mathrm{melt}}$. However, the large variation of $419 \Delta^{18} \mathrm{O}_{\text {ol-melt }}$ would require a large and unrealistic temperature range, from $700^{\circ} \mathrm{C}$ for the lowest $\Delta^{18} \mathrm{O}_{\text {ol-melt }}$ to $>2500{ }^{\circ} \mathrm{C}$ for the positive $\Delta^{18} \mathrm{O}_{\text {ol-melt. }}$ 
421 We propose that the measured $\Delta^{18} \mathrm{O}_{\text {ol-melt }}$ variations instead indicate disequilibrium. Lower or

422 higher $\Delta^{18} \mathrm{O}_{\text {ol-melt }}$ compared to theoretical equilibrium require either a process able to shift the 423 equilibrium toward both higher and lower values, or a combination of different processes.

424 Oxygen diffusion along the moving interface between melt and crystal during crystal growth 425 or after melt inclusion entrapment is a process capable of generating isotopic disequilibrium 426 between melt inclusions and their host olivine. Rapid crystal growth can lead to a local 427 disequilibrium in the growth media, creating boundary layers in which elements with the 428 lowest diffusivity in the melt and/or lowest partition coefficients (e.g., S, Cl, P, Al) will 429 concentrate. It has been demonstrated that this process can create melt inclusion compositions 430 with different major elements (Faure and Schiano, 2005; Watson and Müller, 2009), volatiles 431 (S, Cl) and/or P content (Baker, 2008) compared to the bulk melt composition. Oxygen is also 432 a slow diffusing element in relatively dry melts, with ${ }^{16} \mathrm{O}$ diffusing faster than ${ }^{18} \mathrm{O}$ (e.g., 433 Lesher, 2010); therefore, such a boundary layer should have a higher $\delta^{18} \mathrm{O}$ composition than 434 the melt in which the crystal in growing. Melt inclusions from ARP-73-10-03 have major, 435 trace and volatile elements compositions similar to MORB, with no enrichment in $\mathrm{Al}, \mathrm{S}, \mathrm{Cl}$ or $436 \mathrm{Ca}$; however, some melt inclusions within this sample do have higher $\mathrm{P}$ contents due to 437 olivine dissolution near P-rich (fast growing) domains (Manzini et al., 2017). No significant 438 difference in $\delta^{18} \mathrm{O}_{(\mathrm{Ol})}$ between P-rich and P-poor domains within each olivine are observed 439 (Figure DR2). Moreover, $\delta^{18} \mathrm{O}_{(\mathrm{Ol})}$ compositions of the recrystallized olivine (P-depleted halo) 440 are similar to those of the primary olivine (Figure $6 \mathrm{~A}$ ). Figure $6 \mathrm{~B}$ shows the $\delta^{18} \mathrm{O}$ of melt 441 inclusions from both samples, as a function of their location (in primary olivine, or in 442 recrystallized domains), based on phosphorus maps of the host olivines. No systematic shift in $443 \delta^{18} \mathrm{O}$ as a function of the olivine domain in which the melt inclusion is trapped can be 444 resolved. Also, isotopic disequilibrium can be found in melt inclusions trapped in olivine with 445 or without $\mathrm{P}$ zoning (Table DR2), suggesting that the MI-Olivine $\delta^{18} \mathrm{O}$ disequilibrium and 
446 large $\delta^{18} \mathrm{O}$ variations in melt inclusions are not related to initial rapid crystal growth creating

447 P-rich domains, nor to the dissolution of P-rich olivine domains.
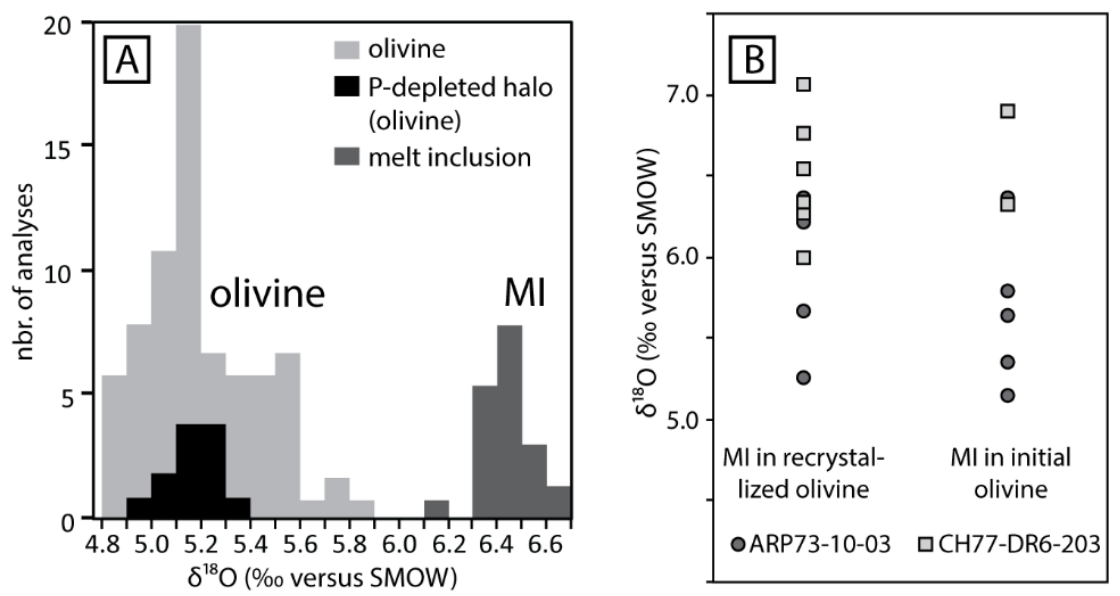

449 Figure 6: A: Comparison of $\delta^{18} \mathrm{O}$ measured in the ARP73-10-03_16 olivine (P-enriched and P-normal 450 zones), in the re-precipitated part (P-depleted zone around melt inclusion) and in the 2 melt inclusions 451 situated in the P-zoned olivine part. No differences in oxygen isotope can be seen between the different parts of the olivine.

B: Comparison of $\delta^{18} \mathrm{O}$ measured in melt inclusions located in recrystallized olivine (i.e. close to a P-zoned region of the olivine) and in unzoned olivine parts, probably in initial olivine, that did not suffer from dissolution and re-precipitation. No differences can be observed between the two populations, but in general CH77-DR6-203 has higher $\delta^{18} \mathrm{O}$ values than ARP73-10-03. As argued above, olivine-hosted melt inclusions within the samples studied here suffered 459 from PEC of olivine. Manzini et al. (2017) have shown that this thin $(<1 \mu \mathrm{m})$ layer crystallizes a few hours before eruption. This fast crystallization results in a strong $\mathrm{P}$ 461 enrichment of the late-crystallized olivine. Post-entrapment crystallization could thus generate 462 a thin boundary layer with a distinct (high) $\delta^{18} \mathrm{O}_{(\mathrm{Ol})}$ composition and lower the initial $\delta^{18} \mathrm{O}$ of 463 the melt inclusions. Given the small volume of the PEC ( $1 \mu \mathrm{m}$ layer compared to melt 464 inclusion diameters of $>50 \mu \mathrm{m}$ ), it should not largely influence the melt inclusion 
composition. This assumption is verified by the absence of a correlation between amount of

466 PEC or P with $\delta^{18} \mathrm{O}$ of the melt inclusions or $\Delta^{18} \mathrm{O}$ ol-melt.

467 Diffusion of $\mathrm{O}$ in and out of the melt inclusions could in theory produce higher or lower $468 \Delta \Delta^{18} \mathrm{O}_{\text {ol-melt. }}$ Oxygen can diffuse as mono or multi-species. Indeed, $\mathrm{O}$ is present in $\mathrm{CO}_{2}$ and $469 \mathrm{H}_{2} \mathrm{O}$ molecules. It is known that water can diffuse in or out of melt inclusions (e.g., Chen et 470 al., 2013; Gaetani et al., 2012; Portnyagin et al., 2008), but mostly in the form of $\mathrm{H}^{+}$. Given 471 the low water content involved in MORB systems, this should not produce large $\delta^{18} \mathrm{O}$ 472 variations in melt inclusions (Zhang and $\mathrm{Ni}, 2010$ ). It is possible that $\mathrm{CO}_{2}$ could largely degas 473 in melt inclusion shrinkage bubbles (e.g., Moore et al., 2015); migration of $\mathrm{CO}_{2}$ in the bubble 474 may fractionate $\delta^{18} \mathrm{O}$, but as ${ }^{16} \mathrm{O}$ is diffusing faster this could only generate higher $\delta^{18} \mathrm{O}$. Melt 475 inclusions with the lowest $\Delta^{18} \mathrm{O}_{\text {ol-melt }}$ do not necessarily contain shrinkage bubbles, which 476 indicates that fractionation of $\mathrm{O}$ isotopes is not related to shrinkage bubble formation.

477 Diffusion of $\mathrm{O}$ after melt inclusion entrapment would imply that melt inclusions were initially not in equilibrium with their host at the time of entrapment and thus cannot explain the origin 479 of the large variation of $\delta^{18} \mathrm{O}$ in the studied melt inclusions. If $\mathrm{O}$ isotopic diffusion occurred 480 after melt inclusion entrapment, it should be limited based on the following observations: 481 First, based on P profiles made from melt inclusions in olivines, melt inclusions were trapped 482 for a few hours to a few days before quenching (Manzini et al., 2017). Using the diffusion 483 data of Dohmen et al. (2002) (this dataset yields a diffusion coefficient of $\sim 9.3 \times 10^{12}$ in olivine 484 at $1250^{\circ} \mathrm{C}$ ), this amount of time would result in a small amount of $\mathrm{O}$ diffusing from melt 485 inclusion to olivine over a profile no longer than 10 microns, which is not resolvable using the 486 techniques employed in this study. This is confirmed by $\delta^{18} \mathrm{O}$ profiles obtained from three 487 different olivines, in which melt inclusions are either in disequilibrium (Figures 7A and DR2) 488 or equilibrium (Figure $7 \mathrm{~B}$ ), starting at $\sim 15-30 \mu \mathrm{m}$ from the inclusion wall, do not show any 489 significant increase or decrease of $\delta^{18} \mathrm{O}$ values toward the MI. Second, $\delta^{18} \mathrm{O}$ profiles measured 
490 within a single melt inclusion, from olivine wall to MI center, give similar values (Figure 8).

491 Lastly, there is no correlation between the melt inclusion size and the $\delta^{18} \mathrm{O}$ value of the melt 492 inclusion.

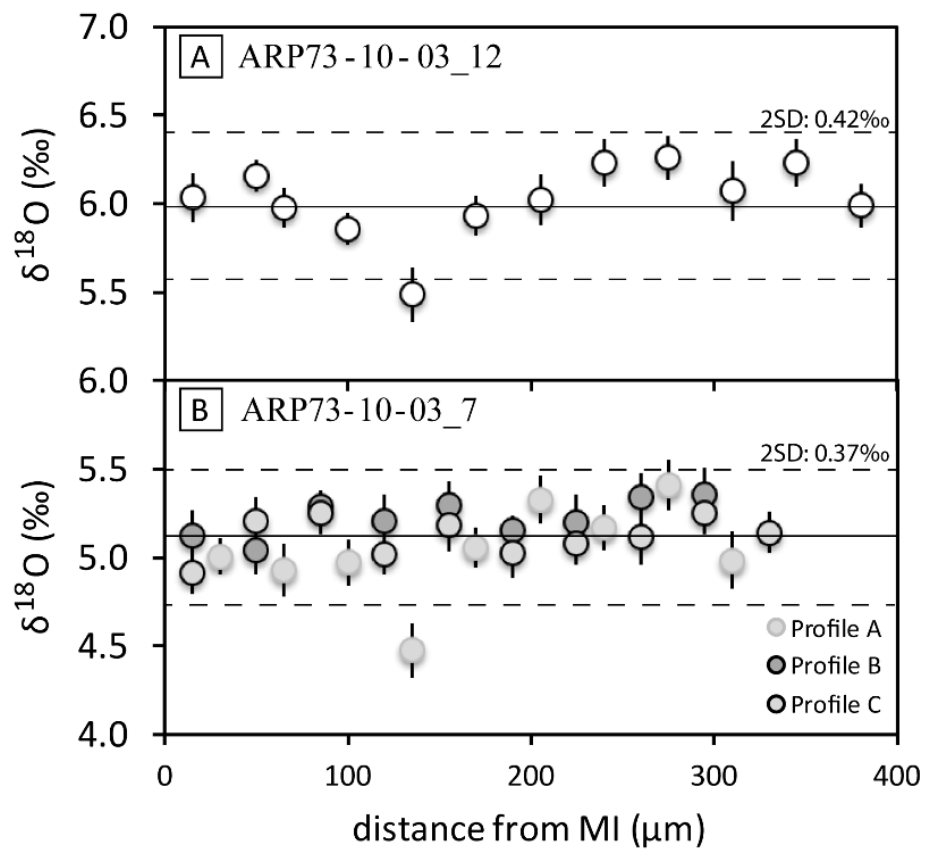

494 Figure 7: Oxygen isotopes profiles in olivines, starting from melt inclusion. A: oxygen isotopes 495 profile in olivine ARP73-10-03_12, for which melt inclusion "a" is not in equilibrium. Profile starts 496 from the melt inclusion. B: different $\delta^{18} \mathrm{O}$ profiles done around the melt inclusion (in equilibrium) 497 entrapped in olivine ARP-10-03_7. The 3 profiles start from 3 different locations around the melt 498 inclusion and all are made in different directions. No clear diffusion profile from the melt inclusion 499 toward the olivine can be observed. Black lines represent the average composition of olivine and 500 dashed lines the $2 \mathrm{SD}$ variations of the data along the profiles. 


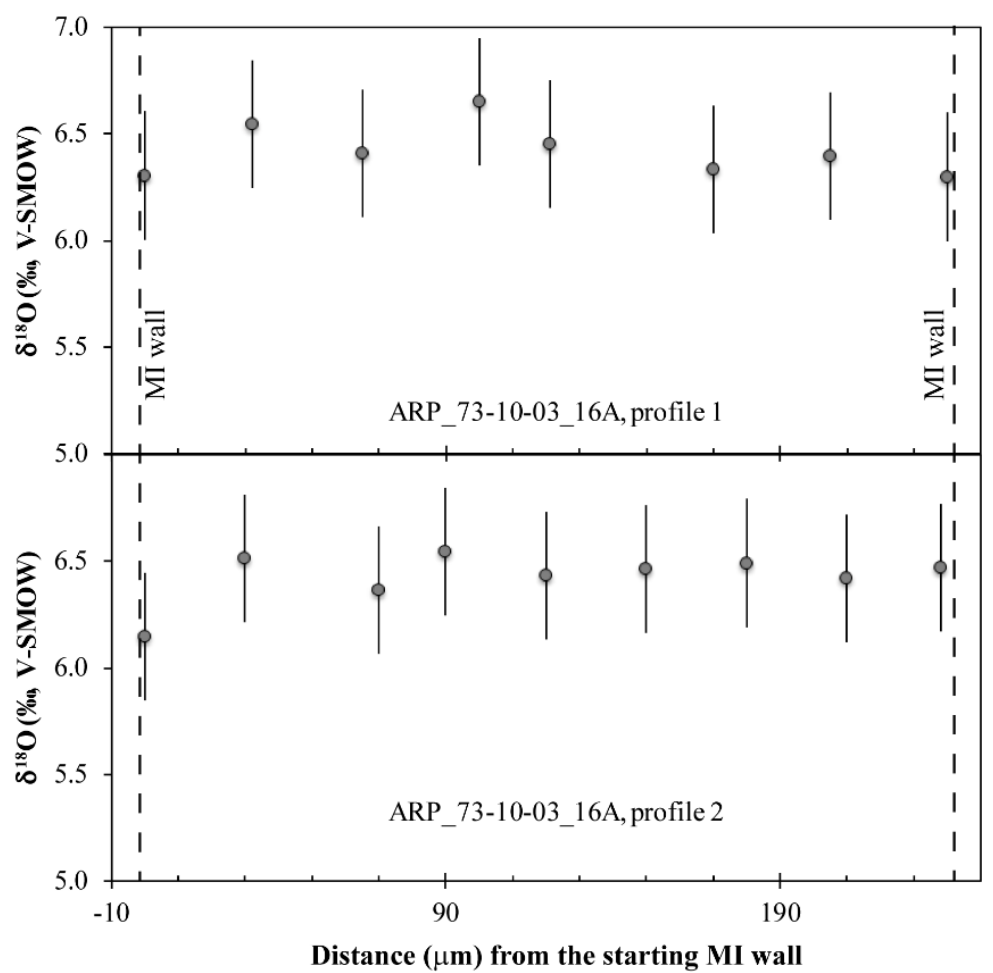

503 Figure 8: Oxygen isotopes profiles in melt inclusion APR-73-10-03_16A, from wall to wall. Two 504 profiles were performed in this melt inclusion, perpendicular to one other.

506 In theory, oxygen diffusion could occur in response to a thermal gradient (Soret diffusion). 507 Indeed, Kyser (1998) and Bindeman et al. (2013) reported significant isotopic fractionation of 508 oxygen isotopes (up to 5.0\%o) in anhydrous basaltic melt due to thermal diffusion, with 509 migration of ${ }^{18} \mathrm{O}$ towards the colder regions. However, such a process has never convincingly 510 been demonstrated in natural samples. Kyser (1998) pointed out that, even if thermally 511 induced diffusion can lead to large $\delta^{18} \mathrm{O}$ fractionation, the rapid decay of thermal gradient $(<$ 51210 days for $100^{\circ}$ gradient at $1 \mathrm{~cm}$ from contact) makes it an unlikely process to happen in 513 natural samples. Given the short timescale associated with the olivine residence time and melt 514 inclusion formation in our samples (Manzini et al., 2017), a locally large thermal gradient (> $515250^{\circ} \mathrm{C}$ ) between migrating magma and conduit walls might be sustained before melt inclusion 516 trapping. Assuming such a scenario, melt inclusions with $\delta^{18} \mathrm{O}$ lower might form in olivine 
517 located in the center of a conduit, whereas melt inclusions with higher $\delta^{18} \mathrm{O}$ would form close

518 to the walls of the conduit; however, olivine crystallizing around the melt inclusions should 519 also have variable $\delta^{18} \mathrm{O}$, which is not observed. This observation indicates that $\mathrm{O}$ diffusion in 520 response to a thermal gradient is not responsible for the $\delta^{18} \mathrm{O}$ variation in melt inclusions.

\section{Concluding remarks}

523 The large variations (up to $2.5 \%$ ) observed in oxygen isotope ratios within melt inclusions

524 from 2 different Atlantic MORB samples (N-MORB and E-MORB) are not correlated with 525 major, trace or volatile elements. Oxygen isotope compositions of host olivines suggest a 526 small $(<1 \%$ o source heterogeneity for each sample. Less than half of the melt inclusions from 527 each sample are in isotopic equilibrium with their host olivines. The remaining melt 528 inclusions have either lower or higher isotopic fractionation compare to theoretical 529 equilibrium values. Boundary layer entrapment will only shift $\delta^{18} \mathrm{O}$ toward higher values, and 530 the present dataset does not support this hypothesis. Fractionation diffusion of $\mathrm{O}$ during $\mathrm{CO}_{2}$ 531 migration into the shrinkage bubble will shift $\delta^{18} \mathrm{O}$ toward lower values, but no evidence of 532 this process has been found. Another process capable of generating $\delta^{18} \mathrm{O}$ fractionation both 533 higher and lower than equilibrium values is $\mathrm{O}$ diffusion in due to the presence of a thermal 534 gradient before melt inclusion entrapment (i.e. Soret diffusion). Although this process could 535 explain the large $\delta^{18} \mathrm{O}$ variation measured, it would imply that a large, unrealistic, thermal 536 gradient $\left(>250^{\circ} \mathrm{C}\right)$ is sustained during the formation of melt inclusions. In addition, the 537 olivine directly surrounding the melt inclusion should also have a different $\delta^{18} \mathrm{O}$ in this 538 scenario, which we do not observe.

539 Despite the marked disequilibrium in a majority of melt inclusions, our data do not show any 540 significant $\mathrm{O}$ diffusion in or out the melt inclusions. This is due to the short residence time at 
541 high temperature after melt inclusion entrapment and the relatively large spatial resolution of

542 the SIMS (10-15 microns). The exact process responsible for the melt inclusion-host $\delta^{18} \mathrm{O}$

543 disequilibrium is thus not yet fully understood. Nonetheless, we argue that this dataset clearly

544 shows that melt inclusions do not necessarily record the $\delta^{18} \mathrm{O}$ composition of the magma in

545 which their host grew. Caution should thus be taken before interpreting $\delta^{18} \mathrm{O}$ variation as

546 source process, especially when not related to any other tracer of common magmatic

547 processes.

548

\section{Acknowledgements}

550 We acknowledge funding by the KIP6 PCI to L. P. Baumgartner. C-J. de Hoog, E. Bloch and

551 O. Müntener are thanked for the useful comments which significantly improved the 552 manuscript. The authors are thankful L. Danyushevsky, and anonymous reviewer and the

553 editor, C. Chauvel, for their helpful reviews and comments. E. F. Rose-Koga acknowledges

554 financial support from the Centre National de la Recherche Scientifique (INSU-SYSTER) and

555 from the Région Auvergne-Rhône-Alpes.

556

557

558 


\section{References}

561 Alt, J.C., 2003. Stable isotopic composition of upper oceanic crust formed at a fast spreading ridge, $562 \quad$ ODP Site 801. Geochemistry, Geophys. Geosystems 4, 1-11. https://doi.org/10.1029/2002GC000400

564 Alt, J.C., Bach, W., 2006. Oxygen isotope composition of a section of lower oceanic crust, ODP Hole 735B. Geochemistry, Geophys. Geosystems 7. https://doi.org/10.1029/2006GC001385

Baker, D.R., 2008. The fidelity of melt inclusions as records of melt composition. Contrib. to Mineral. Petrol. 156, 377-395. https://doi.org/10.1007/s00410-008-0291-3

568 Barnes, J.D., Beltrando, M., Lee, C.T.A., Cisneros, M., Loewy, S., Chin, E., 2014. Geochemistry of Alpine serpentinites from rifting to subduction: A view across paleogeographic domains and metamorphic grade. Chem. Geol. 389, 29-47. https://doi.org/10.1016/j.chemgeo.2014.09.012

571 Bindeman, I.N., Kamenetsky, V.S., Palandri, J., Vennemann, T., 2012. Hydrogen and oxygen isotope behaviors during variable degrees of upper mantle melting: Example from the basaltic glasses from Macquarie Island. Chem. Geol. 310-311, 126-136. https://doi.org/10.1016/j.chemgeo.2012.03.031

Bindeman, I.N., Lundstrom, C.C., Bopp, C., Huang, F., 2013. Stable isotope fractionation by thermal diffusion through partially molten wet and dry silicate rocks. Earth Planet. Sci. Lett. 365, 51-62.

Boschi, C., Dini, A., Früh-Green, G.L., Kelley, D.S., 2008. Isotopic and element exchange during https://doi.org/10.1016/j.eps1.2012.12.037 heterogeneity from trace elements: MAR triple junction near $14^{\circ}$ N. Earth Planet. Sci. Lett. 88 , 
Bucholz, C.E., Jagoutz, O., VanTongeren, J.A., Setera, J., Wang, Z., 2017. Oxygen isotope trajectories of crystallizing melts: Insights from modeling and the plutonic record. Geochim. Cosmochim. Acta 207, 154-184. https://doi.org/10.1016/j.gca.2017.03.027

Chen, Y., Provost, A., Schiano, P., Cluzel, N., 2013. Magma ascent rate and initial water concentration inferred from diffusive water loss from olivine-hosted melt inclusions. Contrib. to Mineral. Petrol. 165, 525-541. https://doi.org/10.1007/s00410-012-0821-x

Cottrell, E., Spiegelman, M., Langmuir, C.H., 2002. Consequences of diffusive reequilibration for the interpretation of melt inclusions. New York 3.

593 Danyushevsky, L. V., Della-Pasqua, F.N., Sokolov, S., 2000a. Re-equilibration of melt inclusions trapped by magnesian olivine phenocrysts from subduction-related magmas: Petrological implications. Contrib. to Mineral. Petrol. 138, 68-83. https://doi.org/10.1007/PL00007664

Danyushevsky, L. V., Eggins, S.M., Falloon, T.J., Christie, D.M., 2000b. $\mathrm{H}_{2} \mathrm{O}$ abundance in depleted to moderately enriched mid-ocean ridge magmas; Part I: Incompatible behaviour, implications for mantle storage, and origin of regional variations. J. Petrol. 41, 1329-1364. https://doi.org/10.1093/petrology/41.8.1329

Danyushevsky, L. V., Leslie, R.A.J., Crawford, A.J., Durance, P., 2004. Melt inclusions in primitive olivine phenocrysts: The role of localized reaction processes in the origin of anomalous compositions. J. Petrol. https://doi.org/10.1093/petrology/egh080

Danyushevsky, L. V., Plechov, P., 2011. Petrolog3: Integrated software for modeling crystallization processes. Geochemistry, Geophys. Geosystems 12. https://doi.org/10.1029/2011GC003516 characterizing plastic flow in the mantle. Geophys. Res. Lett. 29, 2030. trace element data. Eos Trans. AGU 67, 410. 
Eiler, J.M., 2001. Oxygen Isotope Variations of Basaltic Lavas and Upper Mantle Rocks. Rev. Mineral. Geochemistry 43, 319-364. https://doi.org/10.2138/gsrmg.43.1.319

Eiler, J.M., Schiano, P., Kitchen, N., Stolper, E.M., 2000. Oxygen-isotope evidence for recycled crust in the sources of mid-ocean-ridge basalts. Nature 403, 530-534.

614 Faure, F., Schiano, P., 2005. Experimental investigation of equilibration conditions during forsterite 615 growth and melt inclusion formation. Earth Planet. Sci. Lett. 236, 882-898.

$616 \quad$ https://doi.org/10.1016/j.eps1.2005.04.050

617 Frey, F.A., Walker, N., Stakes, D., Hart, S.R., Nielsen, R., 1993. Geochemical characteristics of basaltic glasses from theamar andfamous axial valleys, Mid-Atlantic Ridge $\left(36^{\circ}-37^{\circ} \mathrm{N}\right)$ : Petrogenetic implications. Earth Planet. Sci. Lett. 115, 117-136. https://doi.org/10.1016/0012-

Gaetani, G. a., O’Leary, J. a., Shimizu, N., Bucholz, C.E., Newville, M., 2012. Rapid reequilibration of $\mathrm{H}_{2} \mathrm{O}$ and oxygen fugacity in olivine-hosted melt inclusions. Geology 40, 915-918. https://doi.org/10.1130/G32992.1

Gale, A., Dalton, C.A., Langmuir, C.H., Su, Y., Schilling, J.-G., Dalton, C.A., Langmuir, C.H., Su, Y., Schilling, J., 2013. The mean composition of ocean ridge basalts. Geochem. Geophys. Geosyst 14, 489-518. https://doi.org/10.1029/2012GC004334

Garcia, M.O., Ito, E.M.I., Eiler, J.M., Pietruszka, A.J., 1998. Crustal Contamination of Kilauea Volcano Magmas Revealed by Oxygen Isotope Analyses of Glass and Olivine from Puu Oo Eruption Lavas 39, 803-817.

Genske, F.S., Beier, C., Haase, K.M., Turner, S.P., Krumm, S., Brandl, P.A., 2013. Oxygen isotopes

633 Gurenko, A.A., Bindeman, I.N., Chaussidon, M., 2011. Oxygen isotope heterogeneity of the mantle beneath the Canary Islands: insights from olivine phenocrysts. Contrib. to Mineral. Petrol. 162, 
Gurenko, A.A., Chaussidon, M., 2002. Oxygen isotope variations in primitive tholeiites of Iceland: evidence from a SIMS study of glass inclusions, olivine phenocrysts and pillow rim glasses. Earth Planet. Sci. Lett. 205, 63-79.

Gurenko, A.A., Chaussidon, M., 1997. Boron concentrations and isotopic composition of the Icelandic mantle: evidence from glass inclusions in olivine. Chem. Geol. 135, 21-34.

Gurenko, A.A., Chaussidon, M., 1995. Enriched and depleted primitive melts included in olivine from Icelandic tholeiites: origin by continuous melting of a single mantle column. Geochim.

Harmon, R.S., Hoefs, J., 1995. Oxygen isotope heterogeneity of the mantle deduced from global 180 systematics of basalts from different geotectonic settings. Contrib. to Mineral. Petrol. 95-114.

Hartley, M.E., Thordarson, T., Fitton, J.G., 2013a. Oxygen isotopes in melt inclusions and glasses from the Askja volcanic system, North Iceland. Geochim. Cosmochim. Acta 123, 55-73.

Hartley, M.E., Thordarson, T., Fitton, J.G., 2013b. Oxygen isotopes in melt inclusions and glasses from the Askja volcanic system, North Iceland. Geochim. Cosmochim. Acta 123, 55-73.

Hartley, M.E., Thordarson, T., Taylor, C., Fitton, J.G., EIMF, 2012. Evaluation of the effects of 653 composition on instrumental mass fractionation during SIMS oxygen isotope analyses of glasses. Chem. Geol. 334, 312-323. https://doi.org/10.1016/j.chemgeo.2012.10.027

Helo, C., Longpré, M.A., Shimizu, N., Clague, D.A., Stix, J., 2011. Explosive eruptions at mid-ocean ridges driven by CO 2-rich magmas. Nat. Geosci. 4, 260-263. https://doi.org/10.1038/ngeo1104

Hofmann, A.W., 1988. Chemical differentiation of the Earth : the relationship between mantle, continental crust, and oceanic crust 90, 297-314. 
663 Javoy, M., Pineau, F., 1991. The volatiles record of a "popping" rock from the Mid-Atlantic Ridge at $14^{\circ} \mathrm{N}$ : chemical and isotopic composition of gas trapped in the vesicles. Earth Planet. Sci. Lett. 107, 598-611. https://doi.org/10.1016/0012-821X(91)90104-P

Jin, Z.-M., Green, H.W., Zhou, Y., 1994. Melt topology in partially molten mantle peridotite during ductile deformation. Nature 372, 164.

668

Jochum, K.P., Stoll, B., Herwig, K., Willbold, M., Hofmann, A.W., Amini, M., Aarburg, S., Abouchami, W., Hellebrand, E., Mocek, B., Raczek, I., Stracke, A., Alard, O., Bouman, C., Becker, S., Dücking, M., Brätz, H., Klemd, R., de Bruin, D., Canil, D., Cornell, D., de Hoog, C.J., Dalpé, C., Danyushevsky, L., Eisenhauer, A., Gao, Y., Snow, J.E., Groschopf, N., Günther, D., Latkoczy, C., Guillong, M., Hauri, E.H., Höfer, H.E., Lahaye, Y., Horz, K., Jacob, D.E., Kasemann, S.A., Kent, A.J.R., Ludwig, T., Zack, T., Mason, P.R.D., Meixner, A., Rosner, M., Misawa, K., Nash, B.P., Pfänder, J., Premo, W.R., Sun, W.D., Tiepolo, M., Vannucci, R., Vennemann, T., Wayne, D., Woodhead, J.D., 2006. MPI-DING reference glasses for in situ microanalysis: New reference values for element concentrations and isotope ratios. Geochemistry, Geophys. Geosystems 7, n/a-n/a. https://doi.org/10.1029/2005GC001060

Kamenetsky, V.S., Gurenko, A.A., 2007. Cryptic crustal contamination of MORB primitive melts recorded in olivine-hosted glass and mineral inclusions. Contrib. to Mineral. Petrol. 153, 465481. https://doi.org/10.1007/s00410-006-0160-x

Kelley, K. a., Plank, T., Ludden, J., Staudigel, H., 2003. Composition of altered oceanic crust at ODP Sites 801 and 1149. Geochemistry, Geophys. Geosystems 4, n/a-n/a. https://doi.org/10.1029/2002GC000435

Kempton, P.D., Hawkesworth, C.J., Fowler, M., 1991. Geochemistry and isotopic composition of gabbros from layer 3 of the Indian Ocean crust, Hole 735B. Proc., Sci. results, ODP, Leg 118, Fract. Zo. Drill. Southwest Indian Ridge 127-143. https://doi.org/10.2973/odp.proc.sr.118.118.1991 
Kent, A.J.R., 2008. Melt Inclusions in Basaltic and Related Volcanic Rocks. Rev. Mineral. Geochemistry 69, 273-331. https://doi.org/10.2138/rmg.2008.69.8

Kita, N.T., Ushikubo, T., Fu, B., Valley, J.W., 2009. High precision SIMS oxygen isotope analysis and the effect of sample topography. Chem. Geol. 264, 43-57. https://doi.org/10.1016/j.chemgeo.2009.02.012

Kyser, T.K., Lesher, C.E., Walker, D., 1998. The effects of liquid immiscibility and thermal diffusion on oxygen isotopes in silicate liquids. Contrib. to Mineral. Petrol. 133, 373-381.

Laubier, M., Gale, A., Langmuir, C.H., 2012. Melting and crustal processes at the FAMOUS segment (mid-atlantic ridge): New insights from olivine-hosted melt inclusions from multiple samples. J.

Laubier, M., Schiano, P., Doucelance, R., Ottolini, L., Laporte, D., 2007. Olivine-hosted melt inclusions and melting processes beneath the FAMOUS zone (Mid-Atlantic Ridge). Chem. Geol. Petrol. 53, 665-698. https://doi.org/10.1093/petrology/egr075

Lecuyer, C., Reynard, B., 1996. High-temperature alteration of oceanic gabbros by seawater (Hess

Lesher, C.E., 2010. Self-diffusion in Silicate Melts: Theory, Observations and Applications to Magmatic Systems. Rev. Mineral. Geochemistry 72, 269-309.

Lester, G.W., Kyser, T.K., Clark, A.H., 2013. Oxygen isotope partitioning between immiscible silicate melts with $\mathrm{H}_{2} \mathrm{O}$, P and S. Geochim. Cosmochim. Acta 109, 306-311. composition of the oceanic crust: Implications for Earth's distribution of chlorine. Earth Planet. 
714 Manzini, M., Bouvier, A.S., Baumgartner, L.P., Müntener, O., Rose-Koga, E.F., Schiano, P., Escrig, 715 S., Meibom, A., Shimizu, N., 2017. Weekly to monthly time scale of melt inclusion entrapment 716 prior to eruption recorded by phosphorus distribution in olivine from mid-ocean ridges. Geology 45, 1059-1062. https://doi.org/10.1130/G39463.1

718

Mattey, D., Lowry, D., Macpherson, C., 1994. Oxygen isotope compositions of mantle peridotite. Earth Planet. Sci. Lett. 128, 231-241.

Matthews, A., Stolper, E.M., Eiler, Epstein, S., 1998. Oxygen isotope fractionation among melts, minerals and rocks. Goldschmidt Conf. Toulouse 971-972.

McDonough, W.F., Sun, S. -s., 1995. The composition of the Earth. Chem. Geol. 120, 223-253. https://doi.org/10.1016/0009-2541(94)00140-4

McKenzie, D.P., 1984. The generation and compaction of partial melts. J. Petrol. 25, 713-765. https://doi.org/https://doi.org/10.1093/petrology/25.3.713

Moore, L.R., Gazel, E., Tuohy, R., Lloyd, A.S., Esposito, R., Steele-MacInnis, M., Hauri, E.H., Wallace, P.J., Plank, T., Bodnar, R.J., 2015. Bubbles matter: An assessment of the contribution of vapor bubbles to melt inclusion volatile budgets. Am. Mineral. 100, 806-823.

Naumov, V.B., Dorofeeva, V.A., Girnis, A. V., Yarmolyuk, V. V., 2014. Comparison of major, volatile, and trace element contents in the melts of mid-ocean ridges on the basis of data on inclusions in minerals and quenched glasses of rocks. Geochemistry Int. 52, 347-364. https://doi.org/10.1134/S0016702914050073

Nielsen, R.L., Sours-Page, R.E., Harpp, K.S., 2000. Role of a Cl-bearing flux in the origin of depleted ocean floor magmas. Geochemistry, Geophys. Geosystems 1. https://doi.org/10.1029/1999GC000017

Peres, P., Kita, N.T., Valley, J.W., Fernandes, F., Schuhmacher, M., 2013. New sample holder geometry for high precision isotope analyses. Surf. Interface Anal. 45, 553-556. https://doi.org/10.1002/sia.5061 

552. https://doi.org/10.1016/j.eps1.2008.05.020

742

Schiano, P., 2003. Primitive mantle magmas recorded as silicate melt inclusions in igneous minerals. Earth-Science Rev. 63, 121-144. https://doi.org/10.1016/S0012-8252(03)00034-5

Schilling, J.G., Zajac, M., Evans, R., Johnston, T., White, W., Devine, J.D., Kingsley, R., 1983. Petrologic and geochemical variations along the Mid-Atlantic Ridge from 29 degrees N to 73 degrees N. Am. J. Sci. 283, 510-586. https://doi.org/10.2475/ajs.283.6.510

Seitz, S., Baumgartner, L.P., Bouvier, A.S., Putlitz, B., Vennemann, T., 2017. Quartz Reference Materials for Oxygen Isotope Analysis by SIMS. Geostand. Geoanalytical Res. 41, 69-75. https://doi.org/10.1111/ggr.12133

Shimizu, N., 1998. The geochemistry of olivine-hosted melt inclusions in a FAMOUS basalt ALV 519-4-1. Phys. Earth Planet. Inter. 107, 183-201. https://doi.org/10.1016/S0031-9201(97)001337

Sobolev, A. V., Shimizu, N., 1993. Ultra-depleted primary melt in an olivine fron the Mid-Atlantic Ridge. Nature 363, 151-154.

Stakes, D.S., 1991. Oxygen and hydrogen isotope compositions of oceanic plutonic rocks: Hightemperature deformation and metamorphism of oceanic layer 3. Stable Isot. Geochemistry A Tribut. to Samuel Epstein 77-90.

Tormey, D.R., Grove, T.L., Bryan, W.B., 1987. Experimental petrology of N-MORB near the Kane Fracture Zone: $22-25^{\circ} \mathrm{N}$, mid-Atlantic ridge. Contrib. Miner. Pet. 96, 121-139.

Van Orman, J.A., Grove, T.L., Shimizu, N., 2002. Diffusive fractionation of trace elements during production and transport of melt in Earth's upper mantle. Earth Planet. Sci. Lett. 198, 93-112. https://doi.org/10.1016/S0012-821X(02)00492-2

Wallace, P., Carmichael, I.S.E., 1992. Sulfur in basaltic magmas. Geochim. Cosmochim. Acta 56, 1863-1874. https://doi.org/10.1016/0016-7037(92)90316-B 
765 Watson, E.B., Müller, T., 2009. Non-equilibrium isotopic and elemental fractionation during

766

767

768

769

770

771 Zindler, A., Hart, S.R., Frey, F.A., Jakobsson, S.P., 1979. Nd and Sr isotope ratios and rare earth

772

773 element abundances in Reykjanes Peninsula basalts evidence for mantle heterogeneity beneath Iceland. Earth Planet. Sci. Lett. 45, 249-262. https://doi.org/10.1016/0012-821X(79)90127-4

774

775 
Supplementary material:

778 Figure DR1: Calibration line for IMF correction for oxygen isotope analyses in glasses and 779 olivine.

780 Figure DR2: P-elemental X-ray map of the ARP73-10-03_16 olivine

781 Table DR1: SIMS conditions

782 Table DR2: Major, trace, volatile, elements and $\delta^{18} \mathrm{O}$ composition of melt inclusions

783 Table DR3: Oxygen isotopes in olivines

784 